\title{
Portret młodego pisarza oraz nawiązania do twórczości Antona Czechowa w Dzikiej gruszy Nuriego Bilge Ceylana
}

\begin{abstract}
Domalewski Adam, Portret młodego pisarza oraz nawiązania do twórczości Antona Czechowa w Dzikiej gruszy Nuriego Bilge Ceylana [Portrait of a Young Writer and References to European Literature in Nuri Bilge Ceylan's The Wild Pear Tree]. „Przestrzenie Teorii” 32. Poznań 2019, Adam Mickiewicz University Press, pp. 343-355. ISSN 1644-6763. DOI 10.14746/pt.2019.32.18.

The article focuses on topics related to literature, especially to the works of Anton Chekhov, in the latest film by Nuri Bilge Ceylan The Wild Pear Tree. Its main character, Sinan, is a young writer, while the film is set in the province of Çanakkale, where ancient Troy was located. The analysis of the picture shows that the director refers to the historicity of the myth of the Trojan War with distrust. Instead, Ceylan portrays a local community immersed in intellectual stagnation and creates his hero as an extremely unlikeable misanthropist, to whom literature cannot bring fulfillment. The character of his father, Idris, introduces another ancient motif to the film - the figure of Sisyphus. The relationship between father and son, which deepens in the finale, brings an unexpected note of optimism to the picture, which in its dramaturgy resembles Anton Chekhov's literary worlds.
\end{abstract}

KEYWORDS: Ceylan, Nuri Bilge (1959- ), Turkish cinema, Motion pictures and literature, Trojan war, film analysis

A za dawnych lat, za moich najlepszych młodych lat, kiedy dopiero zaczynałem, całe to pisarstwo było dla mnie jedną nieprzerwaną męka. Pisarzowi bez nazwiska, zwłaszcza gdy nie ma szczęścia, ciagle się wydaje, że jest niezręczny, niezdarny, niepotrzebny, nerwy ma napięte, rozklekotane; natrętnie plącze się koło ludzi ze świata literatury i sztuki, nie uznawany, nie zauważony przez nikogo, boi się patrzeć śmiało i szczerze, jak nałogowy gracz, który nie ma pieniędzy¹.

Przywołany fragment tyrady kierowanej przez Borysa Trigorina do Niny Zariecznej, pochodzacy z II aktu Mewy Antona Czechowa, mówiący o mękach młodego pisarza, stanowi uderzająco trafny opis sytuacji Sinana Karasu, udręczonego bohatera Dzikiej gruszy (Ahlat A ğacl, 2018) - najnowszego filmu Nuriego Bilge Ceylana. Podobieństwo między tym fragmentem a dziełem filmowym tureckiego reżysera wydawać się musi tym większe, że ojciec Sinana, nauczyciel Idris, jest przecież nałogowym graczem, który trwoni wszystkie zarobione pieniądze i dodatkowo zapożycza się u rodziny oraz u znajomych mieszkańców rodzinnego Çan. W niniejszym artykule

${ }^{1}$ A. Czechow, Mewa. Komedia w czterech aktach, [w:] tegoż, Wybór dramatów, przeł. N. Gałczyńska, Wrocław 1979, s. 393. 
chciałbym przyjrzeć się dwóm ważnym wątkom fabularnym Dzikiej gruszy: marzeniu powracającego do rodzinnej miejscowości Sinana o wydaniu własnej książki oraz roli, jaką odgrywają w filmie nawiązania do mitycznych opowieści o Troi i o Syzyfie. Dzika grusza - podobnie jak wcześniejsze dzieła Ceylana ${ }^{2}$ - jest bowiem zarówno głęboko zanurzona w lokalności tureckiej (geograficznej, historycznej oraz społecznej), jak i zawiera wiele odniesień do spuścizny (zwłaszcza literackiej) kultury europejskiej³. Oprócz tego postaram się wskazać znaczące podobieństwa dramaturgiczne między Dzika grusza a pisarstwem Antona Czechowa. Szczególnie interesować mnie będzie sposób ukształtowania i istnienia postaci w dziełach obu twórców. Artystyczne światy przez nich powoływane - odpowiednio filmowe i literackie - wydaja się bowiem dzielić ze sobą szereg charakterystycznych cech, których rozpoznanie pozwoli lepiej zrozumieć i ocenić najnowsze dzieło tureckiego reżysera.

\section{Çanakkale, Troja i koszmary}

Pierwsza scena filmu ukazuje wyjazd Sinana - świeżo upieczonego absolwenta pedagogiki - z leżącego nad cieśniną Dardanele Çanakkale, gdzie studiował, do Çan, miasteczka położonego nieco dalej w głąb historycznej Troady, skąd pochodzi. Zamyślony bohater wpatruje się w morze przy kawiarnianym stoliku (obrazy nakładają się na siebie dzięki podwójnej ekspozycji), po czym - obłożony bagażami - rusza wzdłuż promenady $\mathrm{w}$ kierunku dworca autobusowego. Już samo prowincjonalne miejsce akcji filmu wywołuje skojarzenia z pisarstwem Czechowa. Chociaż bowiem „tło geograficzne literatury Czechowa jest rozległe" ${ }^{4}$ obejmuje oprócz małych

${ }^{2}$ Pierwsze trzy pełnometrażowe filmy reżysera (Miasteczko, Chmury w maju, Uzak) noszące wyraźne ślady autobiograficzne - nazywane bywają anatolijską trylogia. Ich akcja rozgrywa się w Yenice, rodzinnym mieście Ceylana, oraz w Stambule. W kolejnych obrazach poszczególne lokacje także bywały rozpoznawalne i znaczące, na przykład stanowisko archeologiczne Antephellus w Klimatach. Anatolia jako kraina pojawia się w końcu w tytule jednego z późniejszych dzieł reżysera - Pewnego razu w Anatolii. Turcja niewątpliwie była i jest bohaterką filmowych opowieści Nuriego Bilge Ceylana. Zob. L. Raw, Nuri Bilge Ceylan: Rediscovering Anatolia, [w:] tegoż, Six Turkish Filmmakers, Wisconsin 2017, s. 138-166.

${ }^{3}$ Krytyka szczególnie ochoczo przyrównywała jego filmy do utworów dramatycznych Czechowa, sam Ceylan zaś chętnie przyznawał się do wpływu tego autora na swoją twórczość. A. Suner, New Turkish Cinema. Belonging, Identity and Memory, London-New York 2010, s. 90. Odkąd turecki reżyser zaczął odnosić spektakularne sukcesy na arenie międzynarodowej, co znacznie zwiększyło jego możliwości budżetowe i realizacyjne, wpływ ten zaczął być jeszcze bardziej widoczny. Por. Z.C. Ziraman, European Co-Productions and Film Style: Nuri Bilge Ceylan, "Studies in European Cinema" 2019, vol. 16, no. 1, s. 73-89.

${ }^{4}$ E. Polotskaya, Chekhov and his Russia, [w:] The Cambridge Companion to Chekhov, ed. by V. Gottlieb, P. Allain, Cambridge 2000, s. 17. 
wiosek i prowincjonalnych miasteczek także choćby dwie rosyjskie stolice Moskwę i Sankt Petersburg - to, biorąc pod uwagę wyłącznie jego dramaty, tendencja do uprzywilejowania prowincji okazuje się bezsprzeczna ${ }^{5}$. Wraz $\mathrm{z}$ nią pojawia się $\mathrm{w}$ twórczości rosyjskiego pisarza słynna prowincjonalna stagnacja: „apatia, bezruch, niechęć do zmian czy też niemożność ich wprowadzenia" ". Jednocześnie twórczości Czechowa nie znamionuje wyłącznie realizm, ale - jak wielokrotnie podkreślano - pojawiają się w niej istotne odwołania do symbolizmu. Jak podsumowuje Rose Whyman: „Czechow używał poetyckich obrazów i symboli, aby ukazać wewnętrzne doświadczenie, za pomocą którego jego postaci zyskują nowy wgląd i zmieniają własne postrzeganie życia"7. Podobną poetykę mają bez wątpienia także filmy Ceylana, w których ewolucję bohaterów często wyznaczają skojarzone z nimi symbole i sny. Zanim więc nastapi nagłe cięcie i na czarnym tle pojawi się tytuł filmu, widzimy Sinana przechodzącego obok stojącej na miejskim placu konstrukcji przedstawiającej olbrzymiego drewnianego konia. To jedna z turystycznych atrakcji Çanakkale - współczesne wyobrażenie konia trojańskiego, a jednocześnie rekwizyt pochodzący z superprodukcji Troja (Troy, 2004, reż. Wolfgang Petersen), będącej jedyną tego rodzaju ekranizacja epopei Homera. Tym samym Ceylan już na samym początku filmu sygnalizuje, że ulokowanie akcji w prowincji Çanakkale, która pokrywa się mniej więcej z historyczną Troada, gdzie znajdować się miało miasto zdobyte przez Greków podczas wyprawy Agamemnona, stanowić będzie dla jego obrazu istotny kontekst, choćby w postaci antycznej spuścizny i symboliki kojarzonej z tym miejscem.

I rzeczywiście, napomknienia dotyczące bohaterskiej przeszłości - nie tylko antycznej, ale i współczesnej (w 1915 roku wojska tureckie odparły atak dywizjonów oraz marynarki wojennej ententy w cieśninie Dardanele) - pojawiają się w obu rozmowach, które Sinan prowadzi z miejscowymi decydentami, gdy stara się pozyskać środki na wydanie swojej debiutanckiej książki. Zarówno burmistrz, jak i przedsiębiorca Ilhami sugerują mu zajęcie się właśnie przeszłością zamiast „osobistym pamiętnikiem na tematy ogólne”, jak wyraża się włodarz miasta. „To najlepiej zachowane pole bitwy na świecie. Skoro cały świat tak wysoko je ceni, to przecież nie bez powodu" mówi o Gallipoli ${ }^{8}$ właściciel piaskarni. Sinan broni jednak swojego prawa

${ }^{5}$ T. Shakh-Azizova, Chekhov on the Russian Stage, [w:] The Cambridge Companion to Chekhov..., s. 170.

${ }^{6}$ A. Ksenicz, Ścieżkami bohaterów Antona Czechowa, Zielona Góra 2007, s. 179.

${ }^{7}$ R. Whyman, Anton Chekhov, Routledge, London and New York 2011, s. 37-38.

${ }^{8} \mathrm{Z}$ tą areną walk w czasach I wojny światowej związane są dwa anglojęzyczne filmy fabularne: Gallipoli (1981, reż. Peter Weir) oraz Źródto nadziei (The Water Diviner, 2014, reż. Russell Crowe), w wyprodukowaniu których główny udział miała Australia. 
do pisania o ludziach i kulturze własnego regionu poza kontekstem historycznym czy tė̇ merkantylnym copywritingiem turystycznym. „Szczerze mówiąc, uważam, że nie powinno się automatycznie kojarzyć Çanakkale z Troją czy cmentarzem" - oponuje młodzieniec w rozmowie z Ilhamim. I dodaje: „Ja tylko szukam tajemnic życia. Oto pogodny staruszek, który wydaje się znać sekret szczęścia. Jego świat może kryć tajemnicę, która pomogłaby nam wszystkim. A o Troi i cmentarzu napisano tonę identycznych książek". Nie przekonuje to jednak żadnego z rozmówców. Burmistrz odmawia wsparcia, zasłaniając się przepisami zabraniającymi dofinansowania osób prywatnych, zaś zirytowany właściciel piaskarni radzi Sinanowi, by sam nazbierał potrzebna do wydania książki kwotę. Tym samym jednak Sinan dzieli z licznymi bohaterami Czechowa pierwsze znaczące podobieństwo - owo „dążenie “małego człowieka» do samorealizacji”, które zwykle okupione zostaje cierpieniem i niespełnieniem. W opowiadaniach Czechowa, na przykład w Baronie czy Korespondencie, często prowadzi ono zreszta do tragikomicznych sytuacji. I tak jak u rosyjskiego autora, bohater filmu ostatecznie skompromituje się w oczach osoby, na opinii której mu zależy.

Obie zakończone niepowodzeniem rozmowy tylko pogłębiają rozczarowanie i rozgoryczenie początkującego pisarza, a także obrazują kulturalna i intelektualną nędzę jego najbliższego otoczenia. Sinan trafia do Ilhamiego za radą samego burmistrza, który opisuje znajomego przedsiębiorcę jako pasjonata książek, gotowego sfinansować wydanie powieści. Tymczasem wizyta w brzydkim baraku na tyłach kopalni żwiru pozbawia widza wszelkich złudzeń: biblioteka Ilhamiego, którą on sam się szczyci, składa się z kilkunastu książek poustawianych w dwóch rzędach na wąskiej półce. Co gorsza Ilhami zupełnie nie kryje przed Sinanem swojej pogardy dla wykształcenia (mężczyzna porównuje swoją pozycję jako właściciela przedsiębiorstwa do sytuacji znajomych, którzy ukończyli studia i nie wiedzie im się w życiu zbyt dobrze). Okazuje się też, że wcześniejsze dotowanie przez niego książek wynikało z czysto pragmatycznych przesłanek, było rodzajem wdzięczności za płynące z rady miasta kontrakty. Zarówno burmistrz, jak i Ilhami traktuja zatem literaturę skrajnie instrumentalnie, mając na względzie wyłącznie jej ewentualną użyteczność w prowadzeniu interesów lub bieżącej polityki. Gdy Sinanowi ostatecznie uda się wydrukować własnym sumptem debiutancką powieść, rozczarowania dopełni jego najbliższa rodzina. Ani matka, ani siostra w ciagu kilku zimowych miesięcy, jakie mijaja, zanim Sinan ponownie wróci do Çan - tym razem z wojska, nie przeczytaja Dzikiej gruszy. Zreszta sam początkujący autor potrzebne pieniądze uzyska głównie dzięki sprzedaży znalezionych u dziadka starych książek. Inaczej niż we wcześniejszym

${ }^{9}$ A. Ksenicz, dz. cyt., s. 134. 
Zimowym śnie, który był „filmem złożonym z myśli i o myślach”10, tym razem Ceylan konstruuje świat pozbawiony intelektualnego fermentu, pogrążony w marazmie i bezideowości. Jedyną sfera, która rozpala jeszcze gorące dyskusje między Sinanem a jego znajomymi, jest religia, niemniej różnice z imamem Veyselem i Nazmim opisać można jako konflikt między różnymi stopniami tradycjonalizmu. Ten świat budzi także oczywiście skojarzenia ze zbiorowymi portretami Rosjan w wydaniu autora Wiśniowego sadu, który kwestionował poziom kultury umysłowej swoich rodaków, zarzucając im pozbawienie woli czynu i intelektualną apatię ${ }^{11}$.

Nawiązanie do mitu trojańskiego pojawia się w innym jeszcze znaczącym fragmencie filmu, mianowicie w koszmarze, jaki śni się Sinanowi podczas powrotu autobusem z Çanakkale po nieudanym podejściu do centralnego egzaminu nauczycielskiego. Bohater zostaje zauważony, gdy zrzuca do rzeki oderwany fragment rzeźby przedstawiającej syrenę, zdobiącej miejscowy most, po czym nieznajomy mężczyzna rzuca się za nim w pościg. Sinan, z torbą foliową w ręce, ucieka w głąb miasta, przebiega przez waskkie uliczki w zaśmieconej i nieokazałej okolicy, po czym nagle kamera przenosi się na schody we wnętrzu trojańskiego konia - tego samego, który ukazany został w pierwszej scenie filmu. Drewniany pomnik, który ma być schronieniem, okazuje się jednak pułapka - do jego środka przedziera się bowiem mężczyzna i chwyta uciekiniera. Wówczas Sinan zostaje przebudzony z koszmaru, a widz orientuje się, że miał do czynienia z innym poziomem narracji filmowej. Jak słusznie zauważa Magdalena Kempna-Pieniążek, pojawiające się we wszystkich filmach Ceylana motywy oniryczne pełnią w nich szczególną rolę, a sam twórca wydaje się bliski „rozumieniu marzenia sennego jako sposobu poznania, dotarcia do prawdy niedostępnej świadomości, być może nawet niewyrażalnej”" ${ }^{12}$. Koszmar Sinana interpretować można na różne sposoby; niewątpliwie jednak czai się w nim ów lęk posądzenia o bycie „niezręcznym, niezdarnym, niepotrzebnym”, z cytowanej na wstępie wypowiedzi Borysa Trigorina o mękach młodego pisarza.

Warto rozważyć także inny aspekt tego koszmaru, wiążący się z zastanawiająca obojętnością Sinana wobec dziedzictwa kulturowego i historycznego Çanakkale. W końcu na wyobraźnię młodego pisarza mogłaby rzeczywiście oddziaływać siła mitu trojańskiego, skoro - jak pisze Frank Kolb - „wojna

${ }^{10}$ B. Diken, G. Gilloch, C. Hammond, The Cinema of Nuri Bilge Ceylan. The Global Vision of a Turkish Filmmaker, London-New York 2018, s. 119. Autorzy cytowanej pracy pisali dalej o tym filmie, że „prezentuje wiele filozoficznych idei przez koncepcyjnie gęste, ekstrawagancko analityczne sceny”.

${ }^{11}$ Zob. A. Ksenicz, dz. cyt., s. 126-149.

${ }^{12}$ M. Kempna-Pieniążek, Nuri Bilge Ceylan: dalekie miejsca i bliskie twarze, [w:] Autorzy kina europejskiego VII, red. P. Włodek, K. Żyto, Łódź 2018, s. 144. 
trojańska, mityczny wzór konfliktu zbrojnego i zachowań ludzkich w sytuacjach ekstremalnych, zarazem modelowy przykład odpowiedzialności za wojnę, stała się dla kultury antycznej i zachodnioeuropejskiej polem niczym nieograniczonej inspiracji”" ${ }^{13}$, zaś sam homerycki poemat, który zapewnił jej sławę, uchodzi za „początek literatury Zachodu”"14. Tymczasem w śnie Sinana emblematyczny element tego mitu - koń trojański - zostaje pozbawiony przypisywanej mu mocy: staje się pułapka, a nie kryjówka, jak to było w przypadku zmyślnego Odyseuszowego fortelu. Drewniany pomnik wydaje się zresztą „nie pasować” do Çanakkale, nie tylko z powodu umiejscowienia pośrodku współczesnego miasta, ale także ze względu na jawnie sfabrykowane, filmowe pochodzenie konstrukcji. W tym sensie koszmar Sinana rozumieć można dwojako. Albo stanowi on część dokonującej się w filmie Ceylana demistyfikacji antycznej przeszłości miejsca akcji, albo dopełnia portretu Sinana jako człowieka zlęknionego i niezwiązanego bliższą więzia z kulturowym dziedzictwem europejskim.

Można zatem z jednej strony uznać, że Ceylan traktuje w swym filmie owo wyobrażenie konia trojańskiego jako kuriozalny pomnik „historii” - bez wiary w jakakolwiek faktualność wiążącej się z nim opowieści. Interesujacego kontekstu dla Dzikiej gruszy w tym aspekcie dostarcza praca Franka Kolba Zmanipulowana «Troja». Historia - Mity - Polityka. Niemiecki uczony stoi na stanowisku, że odkrycia archeologiczne na wzgórzu Hisarlik w prowincji Çanakkale zostały błędnie uznane za ruiny antycznej Troi, a winę za szereg nieścisłości, a nawet uchybień w naukowym rozumowaniu przypisać należy politycznemu instrumentalizowaniu tego miejsca przez różne grupy interesów ${ }^{15}$. Zdaniem Kolba wojna opisana w Iliadzie nie tylko nigdy nie miała miejsca, ale też „w północno-zachodniej Azji Mniejszej nie było nigdy miejscowości o nazwie Troja"16. Jak wyjaśnia Kolb:

Troada była więc sztucznym tworem epiki, a nie krainą historyczna. Występujący w Iliadzie lud Trojan, który jakoby zasiedlał północno-zachodnią Azję Mniejsza, w rzeczywistości nie istniał ani w okresie powstawania poematu, ani wcześniej. Mamy do czynienia z nazwą przejętą z mitu, którego akcja początkowo rozgrywała się na terenie Grecji, wraz z jej przeniesieniem, z uwzględnieniem wszystkich związanych z nią 'wydarzeń', do Azji Mniejszej ${ }^{17}$.

Co prawda w filmie Ceylana próżno szukać podjęcia wprost tego tematu, niemniej sposób potraktowania antycznej spuścizny Çanakkale nasuwa

${ }^{13}$ F. Kolb, Zmanipulowana "Troja». Historia - Mity - Polityka, przekł. L. Mrozewicz, A. Pawlicka, Gniezno 2016, s. 34-35.

${ }_{14}$ Tamże, s. 21.

15 Tamże, s. 257-285.

${ }^{16}$ Tamże, s. 101 (wyróżnienia autora).

${ }^{17}$ Tamże, s. 100. 
podobne skojarzenia. Z drugiej strony warto przywołać słowa Andrzeja Ksenicza, który stwierdza, że „obycie z zagadnieniami cywilizacji europejskiej [...] to kolejna Czechowowska miara człowieczeństwa, pozwalająca pisarzowi zarysować postać i dowartościować ją lub też ujać jej coś, tak by uczynić ja w oczach czytelnika mniej pociagającą" ${ }^{18}$. Wydaje się, że podobną rolę pełni w filmie brak zainteresowania Sinana sprawami wykraczajacymi poza jego własne doświadczenie. W ten sposób Ceylan dodatkowo zniechęca widzów do głównej postaci, którą portretuje wyjątkowo ką́liwie.

\section{Pisarz nienawidzący ludzi}

Protagoniści większości obrazów tureckiego reżysera związani są ze sztuką. W dotychczasowych filmach znaleźć można było wśród nich: reżysera filmowego (Chmury w maju, 1999), fotografa (Uzak, 2002), wykładowcę historii sztuki (Klimaty, 2006) czy byłego aktora (Zimowy sen, 2014). Pisarz pojawia się w tym gronie po raz pierwszy, niemniej Sinan dzieli z bohaterami wcześniejszych filmów Ceylana wiele wspólnych cech. Magdalena Kempna-Pieniążek pisząc o melancholii typowej dla głównych męskich postaci u tego reżysera, zauważa: „Mahmut, Muzaffer, Isa i Aydin to przecież artyści - warto dodać: rozczarowani artyści, którzy (być może) wierzyli niegdyś w możliwość odnalezienia w sztuce jakiejś prawdy. Nie osiagnąwszy jej, kwestionują sens sztuki [...], równocześnie negując własną tożsamość jako artystów”"19. Autorka dodaje, że ci właśnie bohaterowie-egocentrycy portretowani są w wyjątkowo niekorzystny sposób, a za ich pośrednictwem Ceylan „wymierza ostrze swej krytyki w samego twórcę"20, dając dowód swemu zwątpieniu w mimetyczne i poznawcze możliwości sztuki, a także stawiając wyraźna granicę dla możliwości jej etycznego oddziaływania. Asuman Suner, komentując tę samą cechę twórczości Ceylana, czyli zastanawiająco częsta „obecność niesympatycznych postaci” przypominajacych samego reżysera, widzi w niej ,strategię blokowania identyfikacji” ${ }^{21}$ widzów z filmowymi bohaterami. Ta dystansujacca strategia - zdaniem badaczki ma na celu pobudzenie wrażliwości i czujności odbiorcy na kreowane w filmach sytuacje oraz ich audiowizualne ukształtowanie.

Sinan bez wątpienia należy do najbardziej odpychających postaci w dorobku Ceylana. Dziennikarz Daniel Kasman, jeden z korespondentów festiwalu w Cannes w 2018 roku, podczas którego film miał swoją premierę,

\footnotetext{
${ }^{18}$ A. Ksenicz, dz. cyt., s. 172.

${ }^{19}$ M. Kempna-Pieniążek, dz. cyt., s. 139-140.

${ }^{20}$ Tamże, s. 141.

${ }^{21}$ A. Suner, dz. cyt., s. 93.
} 
pisał: „Nie było mniej sympatycznego bohatera filmowego wśród obrazów, które widziałem w Cannes. Arogancki, zawzięty i do bólu szczery, Sinan wydaje się dręczyć praktycznie każdego, z kim rozmawia, swoim złośliwym uśmieszkiem i mimowolnie agresywnym sarkazmem" ${ }^{22}$. Ten barwny opis doskonale pasuje do bohatera Dzikiej gruszy, który nawet wówczas, gdy stara się być grzeczny, ostatecznie obraża i irytuje rozmówców, jak podczas wspomnianych wizyt u burmistrza i właściciela piaskarni. Inna kluczowa dla zbudowania sylwetki bohatera rozmowa ma miejsce w księgarni, gdzie przypadkowo spotyka on znanego miejscowego pisarza, Sulejmana. Sinan nie przepuszcza okazji („natrętnie plącze się koło ludzi ze świata literatury”) i wdaje się z - początkowo przyjaźnie do niego nastawionym - mężczyzna w dysputę. W ciągu kilku minut młodzieniec daje upust swej frustracji, oskarża Sulejmana i innych lokalnych pisarzy o przeciętność i żenująca autoreklamę, słowem - nie potrafi pohamować swej arogancji. W postawie Sinana ewidentnie przejawia się zazdrość nieznanego nikomu, początkującego pisarza wobec cieszącego się większą popularnością rywala. Swoimi niesłabnacymi, choć zakamuflowanymi atakami zraża do siebie pisarza, który w finale rozmowy jest już całkiem rozsierdzony. Sulejman w rewanżu nazywa młodzieńca „nieuleczalnie opętanym romantykiem” i odchodzi. Przykra wymiana zdań płynnie przechodzi w opisywaną już scenę sennego koszmaru. „Tam, gdzie pojawiają się przed nami wykształceni bohaterowie, którzy nie radzą sobie ze swoimi problemami - co szczególnie widoczne jest w sztukach Czechowa - to jest on wtedy bezlitosny [...]"23 - pisze Andrzej Ksenicz, i równie dobrze można odnieść jego słowa do twórczości filmowej Nuriego Bilge Ceylana.

Scena konfrontacji z Sulejmanem znajduje swe dopełnienie także w trakcie domowej rozmowy Sinana z matka, podczas której mówi on otwarcie o tym, że nie lubi ludzi. „Nie mogę się do tego zmusić. Co mam z tym zrobić? Nie mam nic przeciwko zwierzętom czy przyrodzie. Ale do ludzi nie mam cierpliwości. Nie mogę ich znieść. Jeśli istnieje coś takiego, jak pisarz nienawidzący ludzi..." - zawiesza swój głos Sinan. (Wcześniej w trakcie tej samej konwersacji bohater daje jeszcze wyraz swej mizoginii: „Wszystkie kobiety to wariatki. [...] Tyle w was przesady. Cała ta miłość, cała ta papka emocji. Nie rozumiem, skąd to się bierze"). Na podstawie dotychczasowych uwag można stwierdzić, że Ceylan konstruuje postać Sinana w sposób nieco odmienny od swoich poprzednich protagonistów. Mahmut, Muzaffer, Isa i Aydin - oni wszyscy byli dojrzałymi i zgorzkniałymi mężczyznami, wątpią-

${ }^{22}$ D. Kasman, Cannes 2018. Correspondences \#11: The Dead, the Kyrgyz, and the Writer, $<$ https://mubi.com/notebook/posts/cannes-2018-correspondences-11-the-dead-the-kyrgyz-and-the-writer> [dostęp: 27.08.2019].

${ }^{23}$ A. Ksenicz, dz. cyt., s. 132. 
cymi - jak pisała Kempna-Pieniążek - w sens uprawiania sztuki. W Dzikiej gruszy reżyser przedstawia zaś portret artysty debiutującego, mającego wyidealizowany obraz sztuki oraz wybujałe oczekiwania wobec jej przedstawicieli. Stąd bierze się oczywiście jego hiperkrytycyzm, a po części także - mizantropia. „Nieuleczalnie opętany romantyk” śmiertelnie poważnie traktuje literaturę oraz jej powinności, a zarazem nie umie zaakceptować ludzkich przywar, nie potrafi słuchać innych (matka żali się, że nigdy nie mogła mu się zwierzyć), nie akceptuje i nie rozumie nawet najprostszych uczuć i odruchów. Tak jak bohaterowie wcześniejszych filmów Ceylana, Sinan boi się emocjonalnego zaangażowania i utrzymuje dystans do innych ludzi $^{24}$ (czego najlepszym dowodem jest jego rozmowa ze szkolną miłościa, Hatice, najbardziej zreszta „czechowowska” w całym filmie - w melancholijny sposób traktująca bowiem o wzajemnym rozczarowaniu i życiowym niespełnieniu młodych, dawniej blisko ze sobą związanych postaci).

Trudno więc uznać za zaskakujące, że sztuka nie przynosi mu ukojenia ani spełnienia. Ceylan wyjątkowo w tym względzie nie pozostawia złudzeń: ambicje Sinana spełzną na niczym, gdy znajomy księgarz poinformuje go, że w ciagu minionych kilku miesięcy nikt nie kupił jego „nietuzinkowej autofikcyjnej metapowieści”, jak młodzieniec opisywał swój debiut Sulejmanowi. Nieprzypadkowo także nie oglądamy w filmie ani jednej sceny ukazującej pracę Sinana nad powieścia; tytułowy utwór wydaje się od początku gotowy, czekający tylko na wydanie, najpewniej nie wymaga on - zdaniem bohatera - żadnych zmian i poprawek. Zbieżność tytułu filmu Ceylana z fikcyjna powieścią zawiera oczywiście sugestię, że obraz jest jej ekranizacja, niemniej tytuł ów pozostaje dużo bardziej wieloznaczny. W rozmowach bohaterów pojawia się wspomnienie miejsca zwanego „Dziką Gruszą, takie właśnie drzewo rosło również przed budynkiem szkoły, do której dawniej uczęszczał Sinan. Wreszcie, według jego własnych słów, owoce dzikiej gruszy najpełniej obrazuja „niedostosowanych, samotnych, niekształtnych” mężczyzn $\mathrm{z}$ jego rodziny ${ }^{25}$.

${ }^{24}$ Por. Z. Atam, The Existential Boundaries of Nuri Bilge Ceylan's Cinema: "In the Beginning Was the Father, Why Papa?”, [w:] New Cinema, New Media: Reinventing Turkish Cinema, ed. by M. Akser, D. Bayrakdar, Cambridge 2014, s. 76.

${ }^{25}$ Do podobnych wniosków dochodzi Adam McConnel, który w swoim omówieniu filmu Ceylana sięgną po słownikowe znaczenia obecnego w oryginalnym tureckim tytule przymiotnika 'ahlat'. Autor informuje, że słowo to w swoim slangowym użyciu oznacza niegrzeczna, prostacką osobę (w tym sensie odnosiłoby się ono, rzecz jasna, wprost do Sinana), pozostałe zaś znaczenia (lub wyrazy pokrewne) odsyłaja do biologii oraz związków rodzinnych. Zob. A. McConnel, Reflections (1) on Nuri Bilge Ceylan's "Ahlat Ağace”(The Wild Pear Tree), <http:// www.serbestiyet.com/yazarlar/adam-mcconnel/reflections-1-on-nuri-bilge-ceylans-ahlat-agaci-the-wild-pear-tree-846894> [dostęp: 27.08.2019]. 


\section{Syzyfowe prace}

To ostatnie znaczenie odsyła do drugiej w kolejności najważniejszej postaci w filmie, czyli Idrisa Karasu. Ojciec Sinana - pograżony w długach nauczyciel, wyczekujący przejścia na emeryturę, by móc wreszcie zamieszkać w zrujnowanym, rodzinnym domu na wsi - to figura paradoksalna. Choć jest hazardzistą i utracjuszem, to spośród wszystkich filmowych postaci wzbudza najcieplejsze uczucia. Bohater ten w istocie na wskroś przypomina Ismaila, innego Ceylanowskiego dłużnika, znanego z poprzedniego filmu reżysera, czyli Zimowego snu. W znakomitej analizie tego obrazu autorzy książki The Cinema of Nuri Bilge Ceylan zwracają uwagę, że radykalnemu gestowi Ismaila, odrzucającego oferowaną mu pomoc finansową (bohater wrzuca do ognia cały plik banknotów), towarzyszy subtelny uśmiech na jego twarzy $^{26}$. Czyn, który najłatwiej zaklasyfikować jako niezrozumiały i autodestrukcyjny, zdaniem badaczy ma jednak głębszy wymiar: dzięki niemu Ismail obnaża obłudę i nihilizm logiki, wewnątrz której tkwią pozostali bohaterowie, skupieni na sprawach długu i winy, pozbawieni jakiegokolwiek zewnętrznego punktu odniesienia dla swego materializmu ${ }^{27}$. Ów „nikczemny bohater" - jak piszą autorzy - przypomina niektóre postaci z powieści Fiodora Dostojewskiego: wie, że jest cyniczny i zły, ale świat wokół niego jest jeszcze gorszy ${ }^{28}$. W tym sensie jego „czysto «zły»” akt - będący jawnym antagonizmem, „przeciw-darem”, bezwzględnym ekscesem - wprowadza do świata element „niemożliwy”, który czerpie siłę od uwolnionego ze społecznych norm pragnienia ${ }^{29}$.

Idris w oczywisty sposób postępuje podobnie. Jego kolejnym porażkom towarzyszy nieodłączny uśmiech. Jako nauczyciel traci on swoja pozycję społeczną i naraża na szwank swoją reputację, przegrywając kolejne pieniądze, nie traci jednak nigdy dobrego humoru. Jest ciagle skory do zabawy $^{30}$ (by wspomnieć tylko łapanie żaby podczas wspólnej pracy przy studni) oraz szczeniackiego płatania figli (jak wówczas, gdy dzięki zabawce zarekwirowanej uczniowi razi prądem swoją córkę). Ojciec Sinana potrafi być też prowokacyjny, gdy bezczelnie wraca do domu taksówką zaraz po tym, gdy jego synowi zginęły z kurtki pieniądze. Ostatecznie sam wycofuje się ze społecznej wspólnoty, gdy po przejściu na emeryturę wybiera życie w odosobnieniu w skrajnie nędznych warunkach. Idris woli towarzystwo

${ }^{26}$ B. Diken, G. Gilloch, C. Hammond, dz. cyt., s. 130.

27 Tamże, s. 130-133.

${ }^{28}$ Tamże, s. 131.

${ }^{29}$ Tamże, s. 134.

${ }^{30} \mathrm{Na}$ temat roli zabawy, która w filmach Ceylana nigdy nie jest niewinna, zob. A. Suner, dz. cyt., s. 109. 
zwierząt, co przydaje mu dodatkowego uroku (przyznaje to nawet po latach udręczona wspólnym życiem matka Sinana). Gdy zniknie jego ukochany pies, mężczyzna będzie go wytrwale poszukiwał, zresztą prawdopodobnie ponosi w ten sposób karę od jednego z wierzycieli. Podobnie więc jak Ismail z Zimowego snu bohater ten obnaża pozorne dobro otaczających go postaci, a nie przejmując się swoimi długami, podważa podstawową, przyjmowana przez innych zasadę równej i sprawiedliwej wymiany dóbr.

Dzięki Idrisowi Ceylan wprowadza jednak do filmu i do swojej twórczości nieobecny wcześniej topos - figurę Syzyfa. Drugi z kolei antyczny wątek pojawia się w Dzikiej gruszy, gdy ojciec prosi Sinana o pomoc w drążeniu studni, co następuje zaraz na początku filmu, po powrocie syna ze studiów. Szybko okazuje się, że w projekt wykopania studni na wzgórzu nie wierzy nikt poza samym Idrisem. Mężczyzna nie ustaje jednak w wysiłkach odnalezienia źródła wody. Także pod tym względem bohater jest więc „szaleńcem”, tym razem dlatego, że - jak mówi Sinan - „nigdy nie daje za wygraną. By skojarzenie z Syzyfem uczynić jeszcze bardziej jednoznacznym, w obrazie pojawia się scena, gdy trzej mężczyźni (oprócz Idrisa i Sinana także nestor Ramazan) próbują wyciagnąć z wydrążonego otworu dużej wielkości kamień, który w ostatniej chwili wyślizguje się z liny i wpada z powrotem na dno. Obrazem tej właśnie studni Ceylan zamyka swój film, jednak w jej wnętrzu pojawia się tym razem - drążący kilofem dno - Sinan. Nic w tym dziwnego, wszak reżyser już we wcześniejszych swoich filmach udowodnił, że „przez wizualne symbole wzmacnia poczucie bezcelowości”"31 wykreowanego świata. Ponownie postępuje on zresztą podobnie do Czechowa i wprowadza do filmu element zaskoczenia. Ksenicz tak pisze o osobliwościach Czechowowskiego świata: „pomimo panującej tam, wydawałoby się, normalności czy powszedniości, wręcz mogą zdarzyć się w nim rzeczy nieprzewidywalne, albo też zupełnie niespodziewanie nastapić zmiany w myśleniu i postępowaniu poszczególnych jednostek" ${ }^{32}$. Najlepszym tego przykładem sa samobójcze śmierci tytułowego bohatera Iwanowa oraz Konstantego w Mewie. Ceylan zaskakuje widza nie tylko ostatnim obrazem, ale także uczuciowym zbliżeniem ojca i syna. Rozpoczyna się ono od tego, że Sinan znajduje w portfelu ojca wycinek z lokalnej gazety, informujący o wydaniu Dzikiej gruszy. Obserwujemy wówczas wzruszenie bohatera, które zostanie jeszcze pogłębione w późniejszej szczerej rozmowie z ojcem. Okazuje się, że Idris jako jedyny przeczytał książkę napisaną przez syna, co więcej - rozpoznał w niej swój niezbyt pochlebny portret, który ocenia jako w pełni uzasadniony i pełnoprawny. Mężczyźni zaczynają zdawać sobie sprawę z łączącej

\footnotetext{
${ }^{31}$ L. Raw, dz. cyt., s. 153.

${ }^{32}$ A. Ksenicz, dz. cyt., s. 184.
} 
ich więzi (podkreśleniu czego służą dwa kolejne, szybko następujące po sobie koszmary senne, jeden Sinana, a drugi Idrisa). Zastapienie ojca w jego wysiłku drążenia studni przez Sinana jest więc częścią większej całości, która - choć nie traci nic ze swojej ambiwalencji płynącej z odniesienia do filozofii egzystencjalizmu - zawiera także niespotykaną dotąd u Ceylana dawkę uczuciowości i bliskości.

Powinowactwo najnowszego obrazu Ceylana z twórczością Czechowa także w finale filmu znajduje swoje potwierdzenie.

Specyfika myślenia egzystencjalnego u Czechowa - pisze Ksenicz - wyraża się w tym, iż jego bohaterowie z zastanawiająca rezygnacją prędzej czy później godza się ze swoją sytuacją. [...] Postacie z opowiadania $U$ znajomych czy sztuk Wujaszek Wania i Trzy siostry życie mają właściwie za soba, choć przecież wujaszek Wania ma dopiero czterdzieści lat, a siostry Prozorówny są o wiele młodsze od niego ${ }^{33}$.

Podobny stan zdaje się sugerować u Sinana Ceylan. Bohater, wcześniej tak krytyczny wobec nałogów i rojeń ojca, teraz zaczyna realizować jego niespełniony plan. Wydaje się przy tym pogodzony z faktem, że nie uda mu się zrobić kariery jako pisarz, skazany jest więc na pozostanie w zamkniętym kręgu rodziny i własnej prowincji. To właśnie błędne koło życia i śmierci oraz powtarzalność losów i błędów popełnionych przez przodków zdaje się podkreślać Ceylan przez odwołanie do figury Syzyfa: wszak są nim w filmie zarówno Sinan, jak i Idris. Ten sam rodzaj fatalizmu i unieruchomienia znaleźć można także w najważniejszych utworach dramatycznych Czechowa.

W swojej analizie filmu Ceylana skoncentrowałem się dotąd na jego fabularnej warstwie, w tym na kreacji głównego bohatera, a także na uderzających podobieństwach między tym obrazem a motywami i wątkami pochodzącymi z utworów Antona Czechowa. Powinowactwa te można zarówno uznać za dowód kunsztu Ceylana scenarzysty, jak i odebrać jako swego rodzaju anachronizm oraz brak dramaturgicznej oryginalności. Wydaje mi się jednak, że jeszcze większego kłopotu dostarcza forma filmowa dzieła, która chciałbym na koniec pokrótce scharakteryzować. Ceylan w swoim najnowszym filmie niespodziewanie odchodzi od opanowanej przez niego do perfekcji estetyki slow cinema, która przyniosła tak znakomite efekty w poprzednich obrazach reżysera. W Dzikiej gruszy twórca ogranicza liczbę charakterystycznych dla tego nurtu długich, statycznych ujęć; zamiast tego stara się dynamizować akcję przez gęstszy montaż oraz śmielej poruszająca się kamerę. Nie daje to jednak tym razem zadowalajacych efektów: film jest bez wattpienia mniej atrakcyjny wizualnie, brakuje w nim choćby majestatycznych ujęć krajobrazów (jak w Pewnego razu w Anatolii) czy też niezwykle pieczołowicie oświetlonych, niemal statycznych kompozycji znanych z ka-

${ }^{33}$ Tamże, s. 57. 
drów Zimowego snu. Dzika grusza - inaczej niż wcześniejsze obrazy twórcy nie wzbogaca jego języka wizualnego. Ekwiwalentem dla wspomnianych osiagnięć Ceylana tym razem miały być sceny „,symbolistyczne”, w których wykorzystano efekt spowolnienia, mający odrealnić i uniezwyklić filmowane elementy natury (np. wiatr porywający opadające, jesienne liście). Zabiegi te nie przynoszą jednak zadowalajaccych rezultatów - wydaje się, że po raz pierwszy w karierze Ceylana zdjęcia w jego filmie ocierają się o kicz. Poza tym odejście od wcześniejszej minimalistycznej estetyki nie pozostało bez wpływu na cały świat przedstawiony, a także na kreację postaci w Dzikiej gruszy. Kunsztowna, acz nazbyt chyba naśladowcza historia opowiedziana w filmie, ideowo i dramaturgicznie odwzorowujaca poetykę dzieł Antona Czechowa, nie znalazła swego dopełnienia w niebanalnej warstwie wizualnej dzieła, dlatego finalnie obraz ten uznać trzeba za rozczarowujący.

\section{BIBLIOGRAFIA}

Atam Z., The Existential Boundaries of Nuri Bilge Ceylan's Cinema: "In the Beginning Was the Father, Why Papa?”, [w:] New Cinema, New Media: Reinventing Turkish Cinema, ed. by M. Akser, D. Bayrakdar, Cambridge 2014.

Czechow A., Wybór dramatów, przeł. N. Gałczyńska, Wrocław 1979.

Diken B., Gilloch G., Hammond C., The Cinema of Nuri Bilge Ceylan. The Global Vision of a Turkish Filmmaker, London-New York 2018.

Kasman D., Cannes 2018. Correspondences \#11: The Dead, the Kyrgyz, and the Writer, $<$ https://mubi.com/notebook/posts/cannes-2018-correspondences-11-the-dead-the-kyrgyz-and-the-writer> [dostęp: 27.08.2019].

Kempna-Pieniażek M., Nuri Bilge Ceylan: dalekie miejsca i bliskie twarze, [w:] Autorzy kina europejskiego VII, red. P. Włodek, K. Żyto, Łódź 2018.

Kolb F., Zmanipulowana «Troja». Historia - Mity - Polityka, przekł. L. Mrozewicz, A. Pawlicka, Gniezno 2016.

Ksenicz A., Ścieżkami bohaterów Antona Czechowa, Zielona Góra 2007.

McConnel A., Reflections (1) on Nuri Bilge Ceylan's "Ahlat Ağacı" (The Wild Pear Tree), $<$ http://www.serbestiyet.com/yazarlar/adam-mcconnel/reflections-1-on-nuri-bilge-ceylans-ahlat-agaci-the-wild-pear-tree-846894> [dostęp: 27.08.2019].

Polotskaya E., Chekhov and his Russia, [w:] The Cambridge Companion to Chekhov, ed. by V. Gottlieb, P. Allain, Cambridge 2000.

Raw L., Nuri Bilge Ceylan: Rediscovering Anatolia, [w:] tegoż, Six Turkish Filmmakers, Wisconsin 2017.

Shakh-Azizova T., Chekhov on the Russian Stage, [w:] The Cambridge Companion to Chekhov, ed. by V. Gottlieb, P. Allain, Cambridge 2000.

Suner A., New Turkish Cinema. Belonging, Identity and Memory, London-New York 2010. Whyman R., Anton Chekhov, Routledge, London and New York 2011.

Ziraman Z.C., European Co-Productions and Film Style: Nuri Bilge Ceylan, "Studies in European Cinema" 2019, vol. 16, no. 1. 
